\title{
BENTUK PEMBINAAN KARIR PUSTAKAWAN \\ DI DINAS PERPUSTAKAAN DAN ARSIP DAERAH PROVINSI JAMBI
}

\author{
Wenny Dastina \\ e_mail: wennywenny30@gmail.com \\ Arsyad Nuzul Hikmat \\ e-mail: arsyadyna14@gmail.com \\ PRODI ILMU PERPUSTAKAAN DAN INFORMASI ISLAM FAH \\ UNIVERSITAS ISLAM NEGERI SULTAN THAHA SAIFUDDIN JAMBI
}

\begin{abstract}
ABSTRAK
Penelitian ini bertujuan untuk mengetahui bentuk pembinaan karir para pustakawan Dinas Perpustakaan dan Arsip Daerah Provinsi Jambi, faktor-faktor kendala dalam pembinaan karir serta upaya yang dilakukan guna mengatasi kendala tersebut.Penelitian ini menggunakan metode kualitatif deskriptif.Teknik pengumpulan data meenggunakan metodeObservasi, Wawancara dan Dokumentasi. Hasil penelitian menunjukkan bahwa bentuk pembinaan karir yang dilaksanakan melalui empat bentuk, yaitu pembinaan melalui pendidikan, pembinaan melalui pelatihan, pembinaan melalui posisi kerja berdasarkan jabatan dan keahlian, serta pembinaan melalui organisasi profesi. Kemudian terdapat beberapa kendala dalam pembinaan karir yaitu kurangnya dana dan kurangnya perhatian dari pemerintah. Upaya yang dilakukan guna mengatasi kendala tersebut yakni menjalin kerja sama dengan Komisi X DPR RI dan Dinas Perpustakaan yang ada di provinsi lainnya, memanfaatkan dan mengelola anggaran dana yang tersedia seoptimal mungkin untuk kemajuan Perpustakaan.
\end{abstract}

Key Words :Pustakawan, Pembinaan Karir, Perpustakaan Umum

\section{A. PENDAHULUAN}

Kebijakan pembinaan karir pustakawan di lingkungan perpustakaan atau lembaga informasi pada hakikatnya lebih dimaksudkan agar masing-masing individu dapat mempersiapkan diri untuk menempuh jenjang karir yang sesuai dengan yang diharapkan ataupun direncanakan agar dapat bekerja secara optimal sehingga mampu berkontribusi dalam meningkatkan mutu dan kualitas lembaga. ${ }^{1}$ Konsep ini sejalan dengan undang-undang perpustakaan No. 43 tahun 2007 yang menyebutkan bahwa pustakawan berhak atas pembinaan karir sesuai dengan tuntutan pengembangan kualitas. ${ }^{2}$ Karena itu, dengan adanya

\footnotetext{
${ }^{1}$ Muhammad Rum \& Anwar Sadat, Pengembangan Karir Pustakawan Di Lingkungan Badan Perpustakaan Dan Arsip Provinsi Jambi:Tinjauan Terhadap Undang-undang No. 43 Tahun 2007. (Jambi: Lembaga Penelitian IAIN STS Jambi, 2013). Hlm. 1

${ }^{2}$ Undang - Undang Republik Indonesia Nomor 43 Tahun 2007 Tentang Perpustakaan. Perpustakaan Nasional RI
} 
pembinaan maka diharapkan seseorang tersebut dapat mengembangkan dan menyempurnakan keahlian yang dimilikinya agar siap untuk menempuh tahapan atau jenjang karirnya sebagai seorang pustakawan.

Konsep pembinaan tidak hanya difokuskan pada sumber daya manusia yang menduduki jabatan struktural saja akan tetapi termasuk juga yang menduduki jabatan fungsional. Salah satu jabatan fungsional yang ada di lingkungan instansi pemerintah adalah jabatan fungsional pustakawan. $^{3}$ yaitu jabatan yang dimiliki oleh seorang pegawai yang telah memenuhi syarat dan kompetensi.

Oleh karena itu, diperlukanlah sebuah pembinaan bagi profesi pustakawan, untuk meningkatkan mutu serta kualitas tiap-tiap pustakawan, terutama pustakawan yang bukan berlatar belakang sarjana Perpustakaan. Mereka akan sangat membutuhkan pembinaan sebelum melaksakan tugas yang diembannya, sebab mereka tidak memiliki latar belakang keilmuan dibidang perpustakaan.

Dengan adanya pembinaan karir, maka akanmempengaruhi perjalanan karir pustakawan tersebut dan nantinya akan mempengaruhi pula kinerjanya. Disinilah dibutuhkan peran dari seorang pemimpin perpustakaan, agar memperhatikan bagaimana kebijakan dan usahanya untuk pembinaan karir pustakawan, dengan pembinaan karir yang benar maka pustakawan diharapkan mampu untuk mendapatkan perjalanan karir yang cemerlang dan sesuai dengan yang diharapkan.

Di lingkungan Dinas Perpustakaan dan Arsip Daerah Provinsi Jambi, Berdasarkan hasil observasi dan wawancara awal peneliti, bahwa terdapat 20 orang pustakawan yang bekerja di DPAD Provinsi jambi, dengan rincian 9 orang pustakawan ahli dan 11 orang pustakawan tingkat terampil. Terdapat beberapa permasalahan di dalam proses karirnya sehingga menghambat proses karir para pustakawan tersebut. Seperti kurangnya pembinaan karir untuk pustakawan, tidak adanya regulasi mengenai pembinaan karir pustakawan.Kondisi seperti ini jelas akan berdampak pada regulasi pembinaan para pustakawan serta pada kemajuan perpustakaan.

\footnotetext{
3 Keputusan Menteri Pendayagunaan Aparatur Negara nomor 132/KEP/M.PAN/12/2002 tentang Jabatan Fungsional Pustakawan dan Angka Kreditnya.
} 


\section{B. METODE PENELITIAN}

Penelitian ini menggunakan metode penelitian Kualitatif dengan pendekatan Deskriptif. Penelitian kualitatif adalah penelitian yang bermaksud untuk memahami fenomena tentang apa yang di alami oleh subjek penelitian, misalnya prilaku, cara deskripsi dalam bentuk katakata dan bahasa pada suatu konteks khusus yang alamiah dan memanfaatkan berbagai metode alamiah. ${ }^{4}$ Peneliti mengumpulkan data yang berserak, merangkaikannya sehingga membangun suatu gambaran yang kompleks dan holistik, menganalisis kata-kata, melaporkan pandangan informan secara terperinci yang keseluruhan langkah penelitiannya dalam setting alamiah.

Metode analisis data menggunakan Reduksi Data, Penyajian Data, Verifikasi Data dan terakhir melakukan Trianggulasi Data yaitu Trianggulasi adalah teknik pemeriksaan keabsahan data dengan memanfaatkan sesuatu yang lain di luar data tersebut, untuk keperluan pengecekan atau sebagai pembanding terhadap data tersebut. Teknik trianggulasi yang banyak digunakan adalah pemeriksaan melalui sumber-sumber lainnya. Patton mengungkapkan yang dikutip oleh Moleong, trianggulasi berarti membandingkan dan mengecek balik derajat kepercayaan suatu informasi yang diproleh melalui waktu dan alat yang berbeda dalam penelitian kualitatif

\section{KAJIAN TEORI}

\section{Pembinaan Karir Pustakawan}

Secara bahasa pembinaan berasal dari kata "bina" yang berarti sama dengan "bangun". Jadi pembinaan dalam arti kegunaanya yaitu merubah sesuatu sehingga menjadi baru yang memiliki nilai-nilai yang tinggi.

Sedangkan secara istilah pembinaan disebut sebagai sebuah perbaikan terhadap pola kehidupan yang direncanakan. Setiap manusia memiliki tujuan hidup tertentu dan ia memiliki keinginan untuk mewujudkan tujuan tersebut. Apabila tujuan hidup tersebut tidak tercapai maka manusai akan berusaha untuk menata ulang pola kehidupannya.Sementara karir secara bahasa adalah sebuah kata yang berasal dari bahasa belanda; Carriere yaitu perkembangan dan kemajuan dalam pekerjaan seseorang. Ini juga bisa berarti jenjang dalam sebuah pekerjaan tertentu. ${ }^{5}$

\footnotetext{
${ }^{4}$ Lexy J. Moelong, Metode Penelitian Kuantitatif. (Bandung: Remaja Rosdakarya, 2010)

${ }^{5}$ Ryan Artiana, Pengaruh Faktor Kepribadian dan Demografi terhadap Komitmen karir. (Semarang: Universitas Diponegoro, 2008)
} 
Berdasarkan pendapat-pendapat diatas maka dapat disimpulkan bahwa pembinaan karir merupakan suatu usaha pengawasan untuk mengubah atau memperbaiki sesuatu menjadi lebih baik serta memiliki nilai yang lebih bermanfaat untuk kehidupan dimasa mendatang.

Pembinaan karir pustakawan diartikan sebagai proses atau pola yang diterapkan sebuah perpustakaan dalam memberikaan pembinaan dan membimbing para pustakawannya secara terarah untuk dapat meningkatkan kualitas dan potensi diri guna meniti dan menapaki karir jabatan ke jenjang yang lebih tinggi. Dengan demikian terdapat kemungkinan besar, model atau bentuk pembinaan antara satu perpustakaan dengan perpustakaan lainnnya memiliki perbedaan. Sebab kebijakan pembinaan karir ini tergantung pada keputusan kepala perpustakaan yang sedang memimpin dan nantinya putusan ini akan merujuk pada UndangUndang No 43 Tahun 2007 sebagai sumber hukum dilingkungan perpustakaan

\section{Dasar Hukum Pembinaan Karir Pustakawan}

Undang-undang Republik Indonesia Nomor 43 Tahun 2007 Tentang Perpustakaan. Pasal 31, bahwa tenaga perpustakaan berhak atas: (a), penghasilan di atas kebutuhan hidup minimum dan jaminan kesejahteraan social; (b), pembinaan karir sesuai dengan tuntutan pengembangan kualitas; dan (c), kesempatan untuk menggunakan sarana, prasarana, dan fasilitas perpustakaan untuk menunjang kelancaran pelaksanaan tugas

\section{Konsep Pembinaan Karir Pustakawan}

Pembinaan sebagai konsep maka harus disusun sedemikian rupa, sehingga menjamin terciptanya kondisi objektif yang dapat mendorong peningkatan para pegawai. Dengan adanya pembinaan karir pustakawan, maka memberikan kesempatan kepada pustakawan untuk mempersiapkan diri mengembangkan karirnya sepanjang arah itu mencerminkan tujuan dan kemampuannya

Muhammad rum di dalam artikelnya mengemukakan terdapat 4 bentuk pembinaan karir pustakawan yang dapat dilakukan oleh suatu perpustakaan, yaitu: ${ }^{6}$

a. Pembinaan karir pustakawan melalui pendidikan

Pendidikan merupakan indikator penting dalam menentukan kemampuan kerja pustakawan. Pendidikan dan pengalaman kerja merupakan langkah awal untuk melihat kemampuan seseorang. ${ }^{7}$

\footnotetext{
${ }^{6}$ Muhammad Rum, Model Pembinaan Karir Pustakawan di Lingkungan Ikatan Pustakawan Indonesia (IPI) Provinsi jambi. (Jambi: 2013)

${ }^{7}$ Handoko T Hani, Manajemen Sumber Daya Manusia (Ed. 2. Yogyakarta: BPFE-Yogyakarta, 2008). Hlm. 43
} 
Menurut Hasibuan bahwa pendidikan merupakan indikator yang mencerminkan kemampuan seseorang untuk dapat menyelesaikan suatu pekerjaan. Dengan latar belakang pendidikan pula seseorang dianggap akan mampu menduduki suatu jabatan tertentu.Terdapat beberapa macam jenis pendidikan, diantaranya: ${ }^{8}$

1) Pendidikan Formal

Pendidikan pustakawan melalui pendidikan formal dapat dilakukan di lembaga-lembaga pendidikan tinggi, seperti universitas, institut, atau sejenisnya yang menyelenggarakan program diploma, sarjana, magister atau doktor di bidang perppustakaan, dokumentasi dan informasi. Pendidikan formal tersebut dapat dilakukan di dalam maupun di luar negeri.

2) Pendidikan Non Formal

Disamping pendidikan formal, terdapat pula pendidikan non-formal. Pembinaan melalui pendidikan informal bertujuan untuk meningkatkan kualitas pustakawan secara bersama-sama, dan dapat dilakukan melalui pendidikan dan pelatihan (diklat), penataran (up grading), simposium, seminar, lokakarya, kursus, magang (on the job training), studi banding, dan sebagainya.

Pelatihan Diklat (Pendidikan dan Pelatihan) adalah penyelenggaraan proses belajar mengajar guna meningkatkan kecerdasan dan kompetensi, mengembangkan nilai moral, membangun karakter, sehingga bisa mengerjakan tugas sesuai dengan fungsi yang diembannya. Terdapat dua jenis diklat sebagai berikut :

a) Diklat Teknis Perpustakaan, seperti:

(1) Diklat teknis pengelola perpustakaan

(2) Diklat teknis pengenalan perpustakaan

(3) Diklat tenaga ahli perpustakaan

b) Diklat Fungsional, seperti:

(1) Diklat Calon Pustakawan Tingkat Ahli (CPTA)

(2) Diklat Alih Jalur Pustakawan

(3) Diklat Tim Penilai Pustakawan (http://pusdiklat.pnri.go.id)

Terdapat ragam manfaat yang bisa didapatkan oleh para pustakawan yang sering mengikuti pendidikan non formal ini, seperti pengalaman, pengetahuan dan tentu saja sertifikat sebagai tanda bukti.Oleh karena itu pendidikan non formal merupakan salah satu wadah terbaik untuk menambah pengetahuan.

\footnotetext{
${ }^{8}$ Hasibuan, Pengembangan Karir Guru. (Jakarta: Rineka Cipta, 2000)
} 


\section{3) Pendidikan Informal}

Untuk mengembangkan diri, belajar dengan sesama, menimba pengalaman orang lain serta menjalin hubungan dengan rekan sejawat dapat dilakukan melalui pendidikan informal baik secara individual maupun organisasi didalam suatu organisasi profesi. Pembinaan yang bersifat individual antara lain dengan belajar sendiri, terutama dengan membaca, di samping belajar dari pengalaman sendiri atau pengalaman orang lain. Pustakawan dapat belajar dari berbagai sumber, termasuk yang diterbitkan oleh organisasi profesi.Setiap individu dapat mengembangkan dirinya, mengadakan hubungan informal dengan teman sejawat.

Dalam jaringan ilmuwan dikenal dengan istilah "invisible college", yaitu kegiatan komunikasi yang dilakukan sesama ilmuwan melalui jalur-jalur informal.Dengan seringnya berdiskusi sesama teman sejawat maka dapat menambah informasi, pengetahuan seputar kepustakawanan.

b. Pembinaan Pustakawan melalui Pelatihan

1) Pelatihan Bimtek (Bimbingan Teknis)

Bimbingan Teknis disingkat Bimtek adalah suatu kegiatan dimana para peserta diberikan pelatihan berupa tuntutan yang bermanfaat dalam meningkatkan komptenesi yang bersifat teknis untuk memecahkan permasalahan dan menyelesaikan pekerjaan. Salah satu contoh Bimtek di bidang perpustakaan adalahBimbingan Teknis bagi pengelola perpustakaan, seperti bimbingan pengkatalogan, pengklasifikasian, penginputan koleksi ke katalog online melalui software Slims, dll

Berikut perbedaan antara Diklat dan Bimtek:

\begin{tabular}{|l|l|l|}
\hline \multicolumn{1}{|c|}{ Perbedaan } & \multicolumn{1}{|c|}{ Bimtek } & \multicolumn{1}{c|}{ Diklat } \\
\hline Substansi & Masalah/kasus & Kompetensi Dasar \\
\hline Metode & Tatap muka/ceramah & Andradogi \\
\hline $\begin{array}{l}\text { Tenaga } \\
\text { Pengajar }\end{array}$ & Narasumber & Widyaiswara \\
\hline Pelaksana & SKPD & Badan Diklat \\
\hline Kurikulum & Tidak ada & Berbasis Kompetensi \\
\hline Peserta & $\begin{array}{l}\text { Semua apparat } \\
\text { pemerintahan/swasta }\end{array}$ & Pejabar Struktural dan Fungsional \\
\hline Tujuan & Penyelesaikan Masalah & Peningkatan Kompetensi \\
\hline
\end{tabular}

Tabel 1 Perbedaan Bimtek dan Diklat 
c. Pembinaan karir pustakawan melalui posisi kerja berdasarkan jabatan dan keahlian

Jabatan adalahkedudukan yang menunjukkan tugas, tanggung jawab, wewenang, dan hak seseorang Pegawai Negeri Sipil dalam suatu satuan organisasi negara (Peraturan Kepala BPN. 2006). Di dalam suatu organisasi pemerintahan maka akan dikenal istilah jabatan struktural dan jabatan fungsional.Jabatan Struktural adalah kedudukan yang menunjukkan tugas, tanggung jawab, wewenang, dan hak seseorang Pegawai Negeri Sipil dalam rangka memimpin suatu sistem organisasi negara.

Sedangkan jabatan fungsional adalah kedudukan yang menunjukkan tugas, tanggung jawab, wewenang dan hak seseorang Pegawai Negeri Sipil dalam suatu satuan organisasi yang dalam pelaksanaan tugasnya didasarkan kepada keahlian dan/atau keterampilan tertentu serta bersifat mandiri.

Agar terjadi pemerataan posisi dalam jabatan yang sesuai dengan keahlian, maka pimpinan harus memahami tugas pustakawan sesuai dengan tingkatannya. Adapun tugas pokok pustakawan sebagai berikut:

1) Pustakawan Tingkat Terampil, yaitu pustakawan yang memiliki ijazah serendahrendahnya D2 perpustakaan, dokumentasi, dan informasi atau diploma lain yang mengikuti Diklat Kepustakawanan. Tugas pokoknya meliputi:

a) Pengorganisasian dan Pendayagunaan koleksi bahan pustaka atau sumber informasi. Meliputi:

(1) Pengembangan koleksi

(2) Pengolahan bahan pustaka atau koleksi

(3) Penyimpanan dan pelestarian bahan pustaka

(4) Pelayanan informasi

b) Pemasyarakatan perpustakaan, dokumentasi dan informasi. Meliputi:

(1) Penyuluhan

(2) Publisitas

(3) Pameran

2) Pustakawan Tingkat Ahli, yaitu pustakawan yang memiliki dasar pendidikan minimal S1 saat pertama kali pengangkatannya sebagai pustakawan. Adapun tugas pokoknya sama dengan pustakawan tingkat terampil tetapi ditambah dengan Pengkajian Pengembangan Perpustakaan, dokumentasi dan informasi. ${ }^{9}$

d. Pembinaan Karir pustakawan melalui Organisasi Profesi

\footnotetext{
${ }^{9}$ Peraturan kepala perpustakaan nasional republik indonesia nomor 11 tahun 2015 tentang petunjuk teknis jabatan fungsional pustakawan dan angka kreditnya, (Perpustakan Nasional Republik Indonesia, 2015
} 
Setiap profesi yang dilakoni oleh individu atau kelompok dalam suatu lembaga maka dibutuhkan lembaga formal yang dapat memberikan ruang untuk berkembang maupun belajar menambah wawasan dan pengalaman. Dibidang perpustakaan, telah banyak berdiri organisasi profesi pustakawan seperti Ikatan Pustakawan Indonesia (IPI), Asosiasi Perpustakaan Sekolah Indonesia (APUSI), Forum Perpustakaan Peguruan Tinggi Indonesia (FPPTI), Jaringan Perpustakaan Peguruan Tinggi Islam Indonesia, dan lainlain.

\section{HASIL DAN PEMBAHASAN}

Penulis memaparkan hasil dan pembahasan mengenai bentuk pembinaan karir Pustakawan di DPAD Provinsi Jambi.

\section{Bentuk pembinaan karir Pustakawan di lingkungan DPAD}

Dinas Perpustakaan dan Arsip Daerah Provinsi Jambi mempunyai bentuk pembinaan karir tersendiri bagi semua pustakawan yang bernaung didalamnya. Pustakawan sendiri adalah Jabatan fungsional yang samaderajatnya dengan jabatan fungsional lainnya seperti dosen, dokter dll, mereka membutuhkan sebuah pembinaan agar bisa mendapatkan hasil yang baik khususnya dalam bidang karir mereka. Perbedaan bentuk pembinaan dari setiap profesi itu dikarenakan sifat, fungsi dan kebutuhan mereka. Di lingkungan DPAD Provinsi Jambi, pembinaan karir yang dilakukan melalui empat bentuk yaitu:

a. Pembinaan melalui pendidikan

Pembinaan melalui pendidikan, diharapkan para pustakawan mampu meningkatkan kemampuan, intelektual, serta pengalamannya sehingga mempunyai bekal dalam usaha meningkatkan karir kepustakawanannya.Jenis Pendidikan yang dimaksud disini terbagi kepada:

1) Pendidikan Formal

Dalam menyelenggarakan pembinaan melalui pendidikan formal.DPAD memberi kesempatan kepada pustakawan untuk mengikuti atau melanjutkan pendidikan formalnya.Pembinaan seperti ini biasanya ditujukan kepada pustakawan tingkat terampil lulusan D2 atau D3 untuk melanjutkan ke jenjang Strata satu (S1) Ilmu Perpustakaan.

Salah seorang pustakawan madya menyatakan bahwa pada tahun 1990-an program melanjutkan pendidikan formal telah berjalan aktif, namun sejak berlakunya otonomi daerah program ini berhenti. 
Akibatnya banyak pustakawan yang tidak melanjutkan pendidikan formalnya sebab terkendala dana dan alasan lainnya.

Sementara itu, dalam beberapa tahun terakhir, pemerintah telah mengadakan beasiswa untuk para Aparatur Sipil Negara (ASN) yang bekerja sebagai pegawai sipil di intansi manapun.

KaSi Pembinaan dan Pengembangan Tenaga Perpustakaan menyatakan bahwa beasiswa tersebut benar adanya dan mereka selalu menyebarkan informasi beasiswa tersebut kepada para pustakawan.Sehingga pustakawan sendiri yang menentukan tindak lanjutnya terkait beasiswa tersebut.

2) Pendidikan Non Formal

Menurut Kasi Perpustakaan dan Arsip Daerah Provinsi Jambi bahwa Perpusnas RI secara rutin mengadakan kegiatan pendidikan non formal semisal Diklat, Semninar dll, dengan mengundang Dinas-dinas perpustakaan di setiap provinsi termasuk DPAD Provinsi Jambi. Dan mereka selalu mengutus pustakawan untuk mengikuti kegiatan tersebut

Adapun ragam bentuk Pendidikan Non Formal yang diikuti oleh Pustakawan yaitu seperti Diklat Alih jalur pustakawan, diklat calon pustakawan tingkat ahli, diklat manajemen perpustakaan, dan lain-lain. Selain itu, bentuk pembinaan melalui pendidikan yang dilakukan lainnya berbentuk:

a) Melibatkan pustakawan untuk menjadi team penilai pada pemilihan perpustakaan teladan yang dilakukan setiap tahunnya untuk dikirim ke tingkat nasional.

b) Melibatkan pustakawan untuk ikut lomba pemilihan pustakawan teladan yang setiap tahunnya diadakan untuk dikirim ke tingkat nasional.

3) Pendidikan Informal

Pendidikan Informal di DPAD Provinsi Jambi Biasanya dilakukan para pustakawan sembari duduk santai bercengkrama bertukar pendapat sembari mengadakan diskusi kecil sesame pustakawan.

Kadis DPAD Provinsi Jambi menyatakan bahwa dirinya setiap hari selalu mengadakan komunikasi aktif dengan para pustakawan, berdiskusi seputar perpustakaan, masalah yang di hadapi pustakawan dalam bekerja serta berbicara mengenai keilmuan perpustakaan.Agar dapat menambah pengetahuan masingmasing. 
Selain itu para pustakawan juga sering mengikuti diskusi dan rapat yang di adakan oleh DPAD yang tentunya membahas tentang masalah ataupun rencana DPAD Provinsi Jambi ke-depannya

Dari temuan-temuan diatas, maka dapat dianalisis bahwa pembinaan melalui pendidikan formal kurang berjalan dengan maksimal, sebab keterbatasan anggaran dari DPAD, sementara pembinaan melalui pendidikan non formal, dan informal telah berjalan dengan baik dan mampu menambah wawasan, pengetahuan, serta pengalaman yang bermanfaat untuk para pustakawan terutama memperbanyak bekal dalam proses perjalanan karirnya.

b. Pembinaan melalui pelatihan

Pelatihan juga merupakan salah satu faktor yang penting untuk meningkatkan dan mengembangkan wawasan seorang pustakawan dalam menunjang kegiatan kepustakawanannya.

Sehingga dapat menciptakan lingkungan kerja yang aktif serta menimbulkan karir yang cemerlang. Diharapkan dengan adanya pelatihan tersebut maka pendidikan yang sebelumnya telah diajarkan mampu diterapkan secara langsung dalam pelatihan yang diikuti atau pekerjaan sehari-hari, sehinggaakan terbekas dan tidak mudah hilang dari ingatan.

KadisDPADProvinsi Jambi menuturkan bahwa DPAD Provinsi Jambi rutin mengirim pustakawannya untuk mengikuti pelatihan-pelatihan yang di adakan oleh Perpusnas.

Selain pelatihan yang diadakan Perpusnas, DPAD provinsi jambi juga memberikan kesempatan yang leluasa kepada para pustakawannya untuk mengikuti pelatihan, seminar, workshop, forum, dan sebagainya yang diadakan oleh instansi Seperti pelatihan teknologi informasi, pelatihan manajemen, dan sebagainya.

DPAD Provinsi Jambi sendiri juga kerap mengadakan pelatihan yang diikuti oleh pustakawannya sendiri yang biasanya menjadi bagian dari panitia.

Dari temuan diatas, maka dapat disimpulkan bahwa pembinaan melalui pelatihan telah berjalan dengan baik walau masih ada kekurangan karna kekurangan dana. Namun DPAD selalu mengusahakan agar pustakawan mengikuti pelatihan-pelatihan kepustakawan yang ada, dengan harapan agar pustakawan tersebut mendapatkan ilmu yang dapat disebarkan kesesama pustakawan

c. Pembinaan melalui posisi kerja berdasarkan jabatan dan keahlian 
Setiap pustakawan memiliki jabatan dan keahlian yang berbeda. Apabila perpustakaan tidak menempatkan pustakawan tersebut sesuai dengan keahlian yang dimilikinya maka sangat jelas pekerjaannya akan jadi lambat dan bias saja tidak sesuai dengan harapan.

Salah seorang Pustakawan Madya menyatakan bahwa penempatan kerja para pustakawan di DPAD Provinsi Jambi sudah tepat dan tidak memiliki masalah, semuanya berdasarka jabatan yang diduduki dan pekerjaan yang dilakukan sesuai dengan skill yang dimiliki. Yang menjadi masalah hanyalah kurangnya SDM pustakawan sehingga Pustakawan senior biasanya mengambil alih pekerjaan yang harusnya di kerjakan oleh pustakawan muda. Dinas Perpustakaan dan Arsip Daerah provinsi jambi memberikan kesempatan kepada para pustakawan untuk menduduki jabatan struktural di perpustakaan, dengan catatan jabatan fungsionalnya diberhentikan sementara (DBS).

Kasi Pembinaan dan pengembangan tenaga perpustakaan, menyatakan bahwa semua pustakawan berhak dan mempunyai kesempatan untuk menduduki jabatan structural. Namun nantinya akan ada syarat tertentu serta yang mengangkat adalah Pemerintah Daerah.

Bagi pustakawan yang meduduki jabatan struktural maka untuk sementara jabatan fungsionalnya akan di cabut hingga ia pensiun atau mengundurkan diri dari jabatan strukrual dengan catatan mengundurkan diri sebelum 2 tahun masa pensiun jabatan fungsionalnya

\begin{tabular}{|c|c|c|c|}
\hline No & Nama & Jabatan Struktural & Sejak \\
\hline 1 & SP & $\begin{array}{r}\text { Kepala Seksi Deposit, Pengembangan } \\
\text { Koleksi, Layanan dan Pelestarian Bahan } \\
\text { Perpustakaan }\end{array}$ & 2017 s/d sekarang \\
\hline 2 & DS & Kepala Seksi Pengembangan Kearsipan & 2017 s/d sekarang \\
\hline 3 & BS & $\begin{array}{r}\text { Kepala Seksi Pengembangan } \\
\text { Pembudayaan Kegemaran Membaca }\end{array}$ & 2012 s/d sekarang \\
\hline 4 & UY & $\begin{array}{r}\text { Kepala Seksi Pembinaan dan } \\
\text { Pengembangan Kelembagaan } \\
\text { Perpustakaan }\end{array}$ & 2009 s/d sekarang \\
\hline 5 & TR & $\begin{array}{r}\text { Kepala Seksi Layanan, Otomasi dan } \\
\text { Kerjasama Perpustakaan }\end{array}$ & 2009 s/d sekarang \\
\hline
\end{tabular}

Tabel 2 Pustakawan yang menjabat Pejabat Struktural

d. Pembinaan melalui Organisasi Profesi 
Pustakawan mempunyai organisasi resmi yakni IPI (ikatan pustakawan Indonesia). Dengan adanya organisasi profesi ini diharapkan pustakawan mampu mengembangkan dan mengasah skill yang dimiliki dengan cara diskusi ilmiah bersama sesama pustakawan, mengikuti Rapat Kerja Nasional, seminar, workshop dan lain-lain yang diadakan oleh IPI.

Kasi pembinaan dan pengembangan tenaga perpustakaan menyatak bahwabanyak pustakawan DPAD Provinsi Jambi yang menjadi anggota IPI Jambi bahkan ada yang menjadi bagian dari Kepengurusan IPI

Kemudian Kadis DPAD Provinsi Jambi menyatakan bahwa dalam waktu dekat dari bulan agustus sekarang akan diadakan pemilihan ketua IPI yang baru sebab ketua-ketua sebelumnya, menurut beliau IPI Jambi masih belum berjalan secara optimal sehingga keberadaannya tidak terlalu memberikan efek kepada pustakawan sebab sepinya dari kegiatan ilmiah yang jarang dilakukan.

Dari temuan diatas, maka dapat dianalisis bahwa pembinaan melalui organisasi profesi, kurang berjalan dengan baik dan optimal, dikarenakan organisasi IPI Jambi tidak berjalan dengan semestinya sebagai wadah pustakawan, sehingga menyebabkan pustakawan yang tergabung sebagai anggota tidak dapat mengembangkan skill nya secara optimal

\section{Faktor - faktor kendala dalam pembinaan karir pustakawan di lingkungan Dinas}

\section{Perpustakaan dan Arsip Daerah Provinsi Jambi}

a. Keterbatasan anggaran dana

DPAD Provinsi Jambi mengalami keterbatsan dana yang didapat dari pemerintah daerah, sehingga dengan keterbatasan ini menganggu proses pembinaan karir para pustakawannya. Untuk saat ini, dana yang didapat difokuskan untuk renovasi gedung perpustakaan serta perbaikan interior dan eksterior perpustakaan yang telah banyak menua dan tak terawatt. Sisa danadi alokasikan untuk kegiatan-kegiatan yang bersifat rutinitas dari kegiatan kepustakawanan. Namun sebagian dari anggaran tersebut ada yang dimanfaatkan untuk kunjungan studi banding ke perpustakaan yang lebih maju

Kadis DPAD Provinsi Jambi menyatakan bahwa DPAD mendapatkan 2 sumber dana yakni dari APBN dan APBD, dua dana ini di sinkronisasikan untuk memenuhi kebutuhan perpustakaan dan pegawai seluruhnya. Karna banyaknya perpustakaanperpustakaan kabupaten, desa dll yang kita urus sehingga dana juga ikut berkurang untuk biaya kebutuhan perpustakaan tersebut. Oleh karena itu DPAD Provinsi Jambi 
memfokuskan satu persatu untuk di kerjakan sesuai dengan hasil kesepakatan musyawarah yang telah di tetapkan.

\begin{tabular}{|l|l|l|l|l|}
\hline No & \multicolumn{1}{|c|}{$\begin{array}{l}\text { Jabatan Pustakawan } \\
\text { Terampil }\end{array}$} & \multicolumn{1}{|c|}{$\begin{array}{l}\text { Jabatan } \\
\text { Pustakawan Ahli }\end{array}$} & \multicolumn{1}{|c|}{ Pendidikan } \\
\hline \multirow{2}{*}{1} & $\begin{array}{l}\text { III/b } \\
\text { Pustakawan } \\
\text { Pelaksana Lanjutan }\end{array}$ & $\begin{array}{l}\text { III/b } \\
\text { Pustakawan } \\
\text { Pertama }\end{array}$ & $\begin{array}{l}\text { Sarjana Ilmu Perpustakaan } \\
\text { UIN STS Jambi }\end{array}$ & 2013 \\
\hline 2 & $\begin{array}{l}\text { III/b } \\
\text { Pustakawan } \\
\text { Pelaksana Lanjutan }\end{array}$ & $\begin{array}{l}\text { III/b } \\
\text { Pustakawan }\end{array}$ & $\begin{array}{l}\text { Sarjana Ilmu Perpustakaan } \\
\text { UIN STS Jambi }\end{array}$ & 2013 \\
\hline
\end{tabular}

Tabel 3 Pustakawan yang telah mengikuti pendidikan S1 Ilmu Perpustakaan

b. Minimnya perhatian dari pemerintah daerah terhadap Profesi Pustakawan dan Perpustakaan

Menurut keterangan dari Kasi pembinaan dan pengembangan tenaga perpustakaan bahwa DPAD Provinsi Jambi kurang mendapa perhatian yang lebih karena pemerintah daerah sekarang berfokus pada sector infrastruktur, pendidikan dan kesehatan.Sehingga perpustakaan tidak selalu mendapat bantuan yang diperlukan untuk pengembangan perpustakaan kedepannya. Kedepannya DPAD Provinsi Jambi berharap pemerintah dapat membantu dan bekerja sama dengan perpustakaan untuk mencerdaskan kehidupan bangsa khususnya masyarakat provinsi jambi

Maka dapat disimpulkan, bahwa Dinas Perpustakaan dan Arsip Daerah Provinsi Jambi menghadapai 2 faktor kendala dalam pembinaan karir. Yaitu Keterbatasan anggaran dana dan kurangnya perhatian dari pemerintah terhadap profesi pustakawan

\section{Upaya yang dilakukan untuk mengatasi kendala pembinaan karir pustakawan di} lingkungan Dinas Perpustakaan dan Arsip Daerah Provinsi Jambi

DPAD Provinsi Jambi menempuh langkah-langkah yang strategis dalam pembinaan karir pustakawan untuk mengatasi kendala yang ada. Menurut keterangan Kasi pembinaan dan pengembangan tenaga perpustakaan upaya yang di tempuh antara lain: 
a. Menjalin Kerja sama dengan Komisi X DPR RI dan Dinas Perpustakaan dan Arsip Daerah Provinsi Lainnya

DPAD Provinsi Jambi berupaya selalu menjalin kerja sama secara intens dengan Komisi X DPR RI yang berfokus pada sektor pendidikan, olahraga dan sejarah.

Dengan tujuan agar mendapat perhatian dan bantuan guna mengembangan perpustakaan yang temasuk pada sektor pendidikan.Terlebih dengan adanya putra daerah jambi yaitu IR. H. A. R Sutan Adil Hendra, maka DPAD mengharapkan melalui kerja sama ini, Bapak Sutan Adil Hendra mampu mewakili DPAD guna menyadarkan para pemerintah daerah agar peduli serta tanggap terhadap perpustakaan. Selain itu DPAD Provinsi Jambi juga mengadakan kerja sama dengan DPAD Provinsi Lainnya seperti DPAD Provinsi D.I Yogyakarta guna mempelajari dan menerapkan hal-hal positif dari DPAD D.I Yogyakarta yang sudah maju khususnya mengenai pembinaan karir para pustakawannya

b. Memanfaatkan anggaran yang ada secara optimal

Dengan keterbatasan anggaran yang dialami DPAD Provinsi Jambi maka seluruh pegawai dan pejabat DPAD sepakat untuk menggunakan anggaran dengan bijak dan menghasilkan sesuatu yang optimal.

Berdasarkan observasi peneliti, tampak jelas penggunaan anggaran untuk renovasi DPAD.Seperti perubahan interior dan tata letak ruangan sirkulasi, referensi, layanan anak-anak, dan lainnya.Selain itu mengadakan kegiatan-kegiatan yang menarik minat para masyarakat untuk sadar pentingnya membaca dan mengenalkan perpustakaan. Seperti Talkshow dengan mengundang Duta Baca Indonesia, mengadakan seminar, pelatihan, Bimtek dan lain-lain

\section{E. KESIMPULAN}

Berdasarkan hasil pembahasan di atas, maka dapat diperoleh beberapa kesimpulan antara lain:

a. Bentuk pembinaan karir pustakawan yang dilakukan di DPAD Provinsi Jambi, dilakukan melaui empat pendekatan yaitu: Pembinaan melalui pendidikan, pembinaan melalui 
posisi kerja berdasarkan jabatan dan keahlian (skill), dan pembinaan melalui organisasi profesi. Secara umum semua pendekatan ini telah berjalan baik, namun tampak kekurangan yang sangat jelas pada pembinaan melalui pendidikan formal, dan pembinaan melalui organisasi profesi. Kedua pembinaan tersebut tidak dapat berjalan secara optimal dikarenakan adanya kendala yang menghambat.

b. Kendala-kendala yang dihadapi Dinas Perpustakaan dan Arsip Daerah Provinsi Jambi dalam pembinaan karir pustakawannya adalah: terbatasnya anggaran dana yang dapat di manfaatkan untuk pembinaan dan minimnya perhatian dari pemerintah daerah provinsi Jambi.

c. Upaya-upaya yang dilakukan Dinas Perpustakaan dan Arsip Daerah Provinsi Jambi untuk mengatasi kendala dalam pembinaan karir pustakawan adalah: Menjalin kerjasama dengan Komisi X DPR RI dan DPAD Provinsi lainnya, dan memanfaatkan anggaran yang tersedia sebaik mungkin. 


\section{DAFTAR PUSTAKA}

Handoko T Hani, Manajemen Sumber Daya Manusia (Ed. 2. Yogyakarta: BPFEYogyakarta, 2008)

Hasibuan, Pengembangan Karir Guru. (Jakarta: Rineka Cipta, 2000)

Http://pusdiklat.pnri.go.id

Keputusan Menteri Pendayagunaan Aparatur Negara nomor 132/KEP/M.PAN/12/2002 tentang Jabatan Fungsional Pustakawan dan Angka Kreditnya.

Lexy J. Moelong, Metode Penelitian Kuantitatif. (Bandung: Remaja Rosdakarya, 2010)

Muhammad Rum, Anwar Sadat, Pengembangan Karir Pustakawan Di Lingkungan Badan Perpustakaan Dan Arsip Provinsi Jambi (Tinjauan Terhadap Undangundang No. 43 Tahun 2007). (Jambi: Lembaga Penelitian IAIN STS Jambi, 2013)

Muhammad Rum, Model Pembinaan Karir Pustakawan di Lingkungan Ikatan Pustakawan Indonesia (IPI) Provinsi jambi. (Jambi: 2013)

Peraturan Kepala Badan Pertanahan Nasional Republik Indonesia No 2 Tahun 2006 Tentang Pola Karier Pegawai Negeri Sipil

Peraturan kepala perpustakaan nasional republik indonesia nomor 11 tahun 2015 tentang petunjuk teknis jabatan fungsional pustakawan dan angka kreditnya, (Perpustakan Nasional Republik Indonesia, 2015)

Ryan Artiana, Pengaruh Faktor Kepribadian dan Demografi terhadap Komitmen karir. (Semarang: Universitas Diponegoro, 2008)

Undang - Undang Republik Indonesia Nomor 43 Tahun 2007 Tentang Perpustakaan. Perpustakaan Nasional RI 